\title{
Innovation Leaders, Modest Innovators and Non-innovative SMEs in Slovakia: Key Factors and Barriers of Innovation Activity
}

\author{
L'ubica LESÁKOVÁ, Petra GUNDOVÁ, Pavol KRÁL', Andrea ONDRUŠOVÁ
}

\begin{abstract}
Matej Bel University in Banská Bystrica, Faculty of Economics, Tajovského 10, Banská Bystrica, Slovakia, lubica.lesakova@umb.sk, petra.gundova@umb.sk, pavol.kral@umb.sk, andrea.ondrusova@umb.sk
\end{abstract}

\begin{abstract}
Background and Purpose: The field of innovation represents for small and medium enterprises (SMEs) a fundamental challenge. If the number of innovative SMEs is to rise, it is necessary to identify key factors determining their innovation activity and eliminate the innovation barriers. The main purpose of the paper is to present the results of primary research focused on identification (evaluation) of key factors and barriers determining innovation activities in Slovak SMEs. The division of SMEs into three groups of enterprises: innovation leaders, modest innovators and non-innovators enables to identify the differences in managers' perception of the main factors and barriers determining innovation activities in various types of SMEs and to formulate policy implications for Slovak SMEs.

Design/Methodology/Approach: Results of the empirical research were processed using MS Excel and the statistical analysis of the data in R3.2.4. statistical system was done. For statistical tests we assumed significance level $(a=0.1)$.

Results: Evaluating the importance of the key factors a majority of enterprises (64.71\%) indicated financial resources as the most important factor for the innovations. There is no statistically significant difference in individual (analysed) factors between innovation leaders, non-innovators and innovation followers (modest innovators). The results gained from Fisher exact test $(p$-value $=0.11$ ) indicated a small difference in evaluating the significance of individual barriers between innovation leaders, non-innovators and modest innovators. Majority of enterprises also see as the main barriers to develop innovation activities bureaucracy and corruption and inappropriate state support of innovation activities.

Conclusion: The main implications (conclusion) coming from the research are basic recommendations for state policy makers as well as SME's managers to foster innovation activities in enterprises. They refer to the areas of financial resources, high-quality human resources, cooperation and participation of SMEs in different networks and clusters, systematic institutional support to SMEs, well-created vision and clearly formulated aims, and willingness of enterprises to innovate. Recommendations are summarised following the results of factor's and barrier's evaluation.
\end{abstract}

Keywords: innovations; small and medium enterprises; factors; barriers; Slovak Republic

\section{Introduction}

Innovations are declared as a priority in all European countries and a number of EU programmes are developed to support innovation activities in small and medium enterprises. Starting up the EU potential for growth is one of the key challenges of the Europe 2020 Strategy (European
Commission, 2010).

Innovations have been long time at the centre of a challenging scientific debate. The management guru Peter Drucker observes that "innovation is the specific tool of entrepreneurs, the means by which they exploit changes as an opportunity" (Drucker, 1985). Trushman, \& Nadler (1996) focus on the firm in noting that "innovation

Received: July 15, 2017; revised: September 22, 2017; accepted: October 21, 2017 
is the creation of any product, service or process which is new to the business unit". Another management guru, Michael Porter, shifts the focus of attention by highlighting that innovation cannot be treated solely from an individual or firm level since the process of innovation is embedded within the national or regional context (Porter, 1990). The OECD definition describes innovation as a restoration and widening of product and market portfolio, as new designing, manufacturing and distributing methods, as implementation of changes in work organization and labour force skills, etc. The guidelines on measurement of innovation the OSLO Manual (OECD, 2005) define innovation as "the implementation of a new or significantly improved product (good or service) or process, a new marketing method, or a new organisational method in business practices, workplace organization or external relations".

Although innovation has been studied already for the second century, so far there is no common definition of it. The current approach to innovations maintains that innovation is a key word for entrepreneurs, it emphasises a global approach to innovations as a philosophy (way of managing enterprises) which influences all parts of transformation process in the enterprise (marketing, research and development, planning, manufacturing, managing, etc.) (Adair, 2009). According to Bessant, \& Tidd (2009), for small and medium enterprises, innovation can be a way to gain a competitive advantage. Cooke, \& Wills (1999) stress that innovations help reinforce the market position or gain a larger market share, increase the effectiveness of operations and improve the reputation. Thus, the ability to compete in innovations plays a very important role as a factor of competitiveness, and strengthening innovation activities is one of the main tasks of all types of businesses.

In the last years the role of innovation on SME's survival has received in theoretical and managerial literature a great deal of attention (Di Cintio, Ghosh, \& Grassi, 2017; Cheah, Lang, Snowden, \& Watts, 2014; Lee, Lee, \& Garett, 2017). Much of the research has expanded its scope and included different types of innovation in the research (Maletič, et al., 2014). The innovation aspect of entrepreneurship has gained critical importance in almost all sectors (Peljko, et al., 2016). A wide range of new themes has appeared. One of them is the identification of key factors and barriers determining innovation activities in SMEs.

\section{Factors and barriers determining innovation in SMEs}

Innovation must be a natural part of any entrepreneurship today. Permanent and regular innovation is becoming a competitive necessity; to be successful in the future requires interrupting conventions (Jones, \& Miller, 2007). This is a time of changes and the only way for an enterprise to be successful is to accept these changes, adapt to them and utilize them.

With the development of innovation processes in all types of enterprises, the growing role of innovations is evident also in small and medium enterprises. Compared to large companies, SMEs have more benefits from the point of view of innovation processes, which can be their innovative advantage. In particular, SMEs have flexible and entrepreneurial management structures that allow them to adapt to the changing market and at the same time have no bureaucratic and administrative constraints. They use informal and effective internal communication, their managers are willing to take risk and they are able to exploit new high-risk markets. In spite of all the above mentioned advantages, small and medium enterprises have also some handicaps - not many of them own research capacities and they face a lot of financial problems.

Most of the previous research has paid attention to the managing innovation in large enterprises (Nooteboom, $\&$ Stam, 2008). A few studies were conducted to discover which factors contribute to innovation efforts in SMEs (Keizer, et al., 2002). Following Keizer, et al. (2002), the factors that have an effect on innovation can be divided into internal and external, where internal variables (indicators) refer to the characteristics and policies of SMEs, while external variables refer to the opportunities that SMEs can seize from their environment. From the various studies of success and failure in innovation, it is possible to compile a checklist of factors affecting innovation activities. For our purposes, it will be helpful to build on the previous research and focus attention on a set of key factors significant for SMEs' innovation (Lesáková, 2014).

In our paper, we deal with a set of key factors that are driving innovation in small and medium enterprises and each of the factors is translated to partial indicators (based on Lesáková, et al., 2016; Nemec, 2014):

- human resources (human potential) - number, structure and competencies of staff, share of highly educated people, leadership;

- financial resources (financial potential) - own funds and funds (private and public) available from financial and non-financial institutions;

- technology (material potential) - state of machinery, structure of production potential, ability to quickly adapt production to the changing needs of the market;

- cooperation with external entities (other enterprises, knowledge centres, universities, research institutions, other stakeholders) - forms of cooperation, participation of SMEs in networks and clusters, support for building partnerships, cooperation between SMEs, research institutions and universities;

- management of innovation activities in enterprises created vision, clearly formulated goals and strategy, organizational structure, willingness to innovate, level of managing innovations in SMEs, organizational culture; 
- system of state support for innovation - forms of innovation support, quality and amount of innovation support.

On the other hand, it is necessary to mention the main barriers to developing innovation activities; we have compiled a checklist of 11 barriers to innovation in Slovak SMEs: lack of internal financial sources, difficulty to obtain external financial sources, high cost of innovation, insufficient qualification of labour, lack of willingness to innovate, absence of innovation strategy, lack of cooperation with external entities, inappropriate system of state support for innovation, bureaucracy, corruption, lack of knowledge about the benefits of R\&D in the enterprise (Lesáková, et al., 2016; Nemec, 2014).

To obtain a complex view of the factors and barriers significant for innovation in SMEs, we divided all enterprises into three categories according to the introduced type of innovation:

1. Innovation leaders (successful innovative enterprises) - enterprises that introduced at least 3 product innovations, 3 process innovations, 5 organizational and 5 marketing innovations in the years $2010-$ 2015.

2. Non-innovators (non-innovative enterprises) - enterprises that did not introduce any product innovation or process innovation in the examined period.

3. Modest innovators (innovation followers) - enterprises that belong neither to the group of innovation leaders nor the group of non-innovators.

Most of the existing research studies devoted to the evaluation of innovation activity in SMEs are based on the division of enterprises into two categories: innovative enterprises and non-innovative enterprises (Hoffman, et al., 1998; Keizer, et. al., 2002; Radas, \& Božič, 2009; Szczepańska-Woszczyna, 2014). The reason why we decided to divide the entire sample of enterprises into more than two categories was to identify the difference in the significance of key factors and barriers determining innovation activities. It is obvious that there are enterprises which can be included neither in the category of innovative enterprises, nor the category of non-innovative enterprises. We used cluster analysis to process our data and it revealed that the enterprises are falling into three categories - the enterprises which are successful in innovation activities (innovation leaders), then the enterprises that could be marked as modest innovators (innovation followers) and the enterprises that do not perform any innovation activities (non-innovative enterprises). The above-mentioned groups of enterprises enable to obtain more accurate results about the key factors and barriers determining innovation activities in SMEs.

\section{Aim, material and methodology}

Theorists from different countries largely acknowledge innovation as a key driver of SME's performance and growth in contemporary market economies (Di Cintio, Ghosh, \& Grassi, 2017). Innovation matters, not only at the level of the individual SME but also increasingly as the wellspring for national economic growth (Bessant, \& Tidd, 2009). Most of the research studies confirm that innovations are the drive of SMEs development advancing the possibilities of their future competitiveness and increasing SME's economic efficiency and performance (Kressel, \& Lento, 2012; Lee, Lee, \& Garett, 2017; Peljko, et al., 2016). For SME's management is therefore the critical task to identify key factors and barriers determining their innovation activities.

This paper aims to present the results of primary research focused on evaluation (identification) of the key factors and barriers determining innovation activities in Slovak SMEs. The division of SMEs into three groups of enterprises: innovation leaders, modest innovators and non-innovators enables to identify the differences in managers' perception of the main factors and barriers determining innovation activities in various types of SMEs and formulate policy implications for Slovak SMEs (recommendations for SMEs as well as policy makers) and thus improve the situation in this area.

Based on the research of different authors $\left(\mathrm{O}^{\prime}\right.$ Sullivan, \& Dooly, 2009; Bessant, \& Tidd, 2009; Keizer, et. al., 2002; Radas, \& Božič, 2009; Szczepańska-Woszczyna, 2014) and our own previous research (Lesáková, 2014), we looked for answers to two main questions:

- Q1 - What are the main differences, if any, in the perception of various factors determining innovation activities in all three segments of SMEs: innovation leaders, modest innovators and non-innovators?

- Q2 - What are the main differences, if any, in the perception of barriers to developing innovation activities in all three categories of SMEs: innovation leaders, modest innovators and non-innovators?

Data for our research were collected in the period from November 2015 to January 2016. We used questionnaire as a method of primary data collection (see Appendix for details). Questionnaire was divided into three parts. The first part was devoted to the evaluation of key factors determining innovation activities, the second one to the evaluation of main innovation barriers and the last one to identification items. The questionnaire was distributed electronically through Google Docs to randomly chosen 998 enterprises of all size types (micro, small, medium size and large enterprises). We sent the questionnaire to top managers of these companies by e-mail. Sixty one of the enterprises responded and sent the completed questionnaire. After reviewing each reply, we set aside the answers 
from large companies, as our research was focused only on SMEs. At the end, we collected 51 valid questionnaires from SMEs. After that, we processed the data through MS Excel, and made a statistical analysis of the data in R 3.2.4 statistical system. Based on criteria listed in Labovitz (1968) we decided to choose $10 \%$ significance level $(\alpha=0.1)$ for statistical tests.

The representativeness of the sample regarding the classification SK NACE (p-value $=0.1594$ ) and region ( $p$-value $=0.2824)$ was tested using Chi-squared goodness of fit test. Based on the test results, we concluded that our sample of enterprises can be seen as a reasonable sample of the entire population of small and medium enterprises.

The sample included $58.8 \%$ of micro enterprises, $23.5 \%$ of small enterprises and $17.7 \%$ of medium enterprises. It consisted mainly of enterprises located in the region of Bratislava (43.1\%), which was most likely caused by the highest concentration of enterprises in this region. The second most frequent representation had enterprises from the region of Banská Bystrica (15.7\%). In the sample, prevailed enterprises (firms) from the sector of manufacturing industry (19.6\%), wholesale and retail (17.7\%) and construction (15.7\%).

According to the division of SMEs into the three categories (innovation leaders, innovation followers and non-innovative enterprises), 13 enterprises were classified as innovation leaders (25.5\%) - in the years 2010 - 2015, they introduced at least 3 product innovations, 3 process innovations, 5 organizational innovations and 5 marketing innovations; 14 enterprises $(27.5 \%)$ can be considered non-innovators - they did not introduce any product innovation or process innovation, and 24 enterprises (47.1\%) were included into the group of innovation followers.

\section{Results}

Data collected by the questionnaire point to a rise of all types of innovations during the analysed period. They confirmed that most enterprises developed innovation activities in the year 2015. The number of individual types of innovations introduced in each year of the examined period is presented in Table 1.

To determine the proportion of enterprises that introduced a certain type of innovation, we used $90 \%$ confidence intervals (Table 2). From Table 2 it is evident that with $90 \%$ confidence, the highest proportion of product innovations were introduced in the year 2015 (from $45.6 \%$ to $71.6 \%$ ), process innovations in the year 2014 (from $46.7 \%$ to $72.3 \%$ ), organizational innovations in the year 2015 (from $0 \%$ to $15.3 \%$ ) and marketing innovations in the year 2015 (from $44.5 \%$ to $70.9 \%$ ).

Based on the research results, we could identify the types of innovations the enterprises introduced. During that period, the best enterprise introduced 20 innovations ( 5 product innovations, 5 process innovations, 5 organizational innovations and 5 marketing innovations) and the worst enterprise did not report any type of innovation. On average, the enterprises in our sample introduced 12.29 $(\mathrm{SD}=5.25)$ innovations in the analysed period.

The first part of the questionnaire was focused on evaluation of the factors significant for innovation in Slovak SMEs. We created a checklist of six key factors: human resources, financial resources, technology, cooperation with other entities, management of innovation activities in enterprises and system of state support for innovation.

We assumed that Slovak SMEs do not evaluate the significance of these factors in the same way. To verify this premise, we used the Friedman test. This test rejected the null hypothesis that none of the factors is seen by Slovak

Table 1: Type of introduced innovations

\begin{tabular}{|c|c|c|c|c|c|c|}
\hline Type of innovation & $\mathbf{2 0 1 5}$ & $\mathbf{2 0 1 4}$ & $\mathbf{2 0 1 3}$ & $\mathbf{2 0 1 2}$ & $\mathbf{2 0 1 1}$ & $\mathbf{2 0 1 0}$ \\
\hline Product innovations & 26 & 22 & 24 & 14 & 11 & 11 \\
\hline Process innovations & 24 & 27 & 18 & 16 & 10 & 12 \\
\hline Organizational innovations & 25 & 20 & 10 & 9 & 9 & 7 \\
\hline Marketing innovations & 22 & 19 & 14 & 4 & 6 & 8 \\
\hline
\end{tabular}

Table 2: 90\% confidence interval for share of enterprises according to the type of innovation (\%)

\begin{tabular}{|c|c|c|c|c|c|c|}
\hline Type of innovation & $\mathbf{2 0 1 5}$ & $\mathbf{2 0 1 4}$ & $\mathbf{2 0 1 3}$ & $\mathbf{2 0 1 2}$ & $\mathbf{2 0 1 1}$ & $\mathbf{2 0 1 0}$ \\
\hline Product innovations & $45.6-71.6$ & $36.8-63.2$ & $41.1-67.5$ & $20.4-45.2$ & $14.7-38$ & $14.7-38$ \\
\hline Process innovations & $40.1-66.2$ & $46.7-72.3$ & $27.7-53.3$ & $23.7-48.9$ & $12.6-34.8$ & $16.2-39.6$ \\
\hline Organizational innovations & $0-15.3$ & $0-12.2$ & $0-8.7$ & $0-8.4$ & $0-8.4$ & $0-8$ \\
\hline Marketing innovations & $44.5-70.9$ & $33.3-60.1$ & $13.2-36.2$ & $11.4-33.7$ & $11.4-33.7$ & $7.9-28.4$ \\
\hline
\end{tabular}


SMEs as more or less important than the others (p-value $=9.066 \mathrm{e}-14$ ) and supported our assumption that Slovak SMEs perceive the key factors significant for their innovation differently.

Evaluating the importance of the key factors (Table 3 ), a majority of enterprises (64.7\%) indicated financial resources (average 3.56) as the most important factor for their innovations. Another two factors - human resources and technology - had the same average (3.03), but 20 en- terprises (39.2\%) indicated human resources as the most important factor of innovation activity in the enterprise. Technology as the most important factor was indicated by 15 enterprises $(29.4 \%)$. Critical is the finding that 35 enterprises $(68.6 \%)$ consider cooperation with external partners as a factor of low importance.

To compare the significance of individual factors determining innovation activities in Slovak SMEs, we used a graphical presentation by box plots. Graph 1 shows that

Table 3: Factors determining innovation activities in Slovak SMEs

\begin{tabular}{|c|c|c|c|c|c|}
\hline \multirow{2}{*}{ Factors } & \multicolumn{5}{|c|}{ The importance of factors } \\
\hline & The lowest (1) & Lower (2) & Higher (3) & The Highest (4) & Average \\
\hline Human resources & $\begin{array}{c}5 \\
(9.80 \%)\end{array}$ & $\begin{array}{c}8 \\
(15.69 \%)\end{array}$ & $\begin{array}{c}18 \\
(35.29 \%)\end{array}$ & $\begin{array}{c}20 \\
(39.22 \%)\end{array}$ & 3.03 \\
\hline Financial sources & $\begin{array}{c}1 \\
(1.96 \%)\end{array}$ & $\begin{array}{c}2 \\
(3.92 \%)\end{array}$ & $\begin{array}{c}15 \\
(29.41 \%)\end{array}$ & $\begin{array}{c}33 \\
(64.71 \%)\end{array}$ & 3.56 \\
\hline Technology & $\begin{array}{c}3 \\
(5.88 \%)\end{array}$ & $\begin{array}{c}7 \\
(13.73 \%)\end{array}$ & $\begin{array}{c}26 \\
(50.98 \%)\end{array}$ & $\begin{array}{c}15 \\
(29.41 \%)\end{array}$ & 3.03 \\
\hline Cooperation with external entities & $\begin{array}{c}10 \\
(19.61 \%)\end{array}$ & $25(49.02 \%)$ & $\begin{array}{c}8 \\
(15.69 \%)\end{array}$ & $\begin{array}{c}8 \\
(15.69 \%)\end{array}$ & 2.27 \\
\hline $\begin{array}{c}\text { Management of innovation activi- } \\
\text { ties in enterprises }\end{array}$ & $\begin{array}{c}4 \\
(7.84 \%)\end{array}$ & $\begin{array}{c}24 \\
(47.06 \%)\end{array}$ & $\begin{array}{c}13 \\
(25.49 \%)\end{array}$ & $\begin{array}{c}10 \\
(19.61 \%)\end{array}$ & 2.56 \\
\hline $\begin{array}{c}\text { System of state support for inno- } \\
\text { vation }\end{array}$ & $\begin{array}{c}7 \\
(13.73 \%)\end{array}$ & $\begin{array}{c}14 \\
(27.45 \%)\end{array}$ & $\begin{array}{c}13 \\
(25.49 \%)\end{array}$ & $\begin{array}{c}17 \\
(33.33 \%)\end{array}$ & 2.78 \\
\hline
\end{tabular}

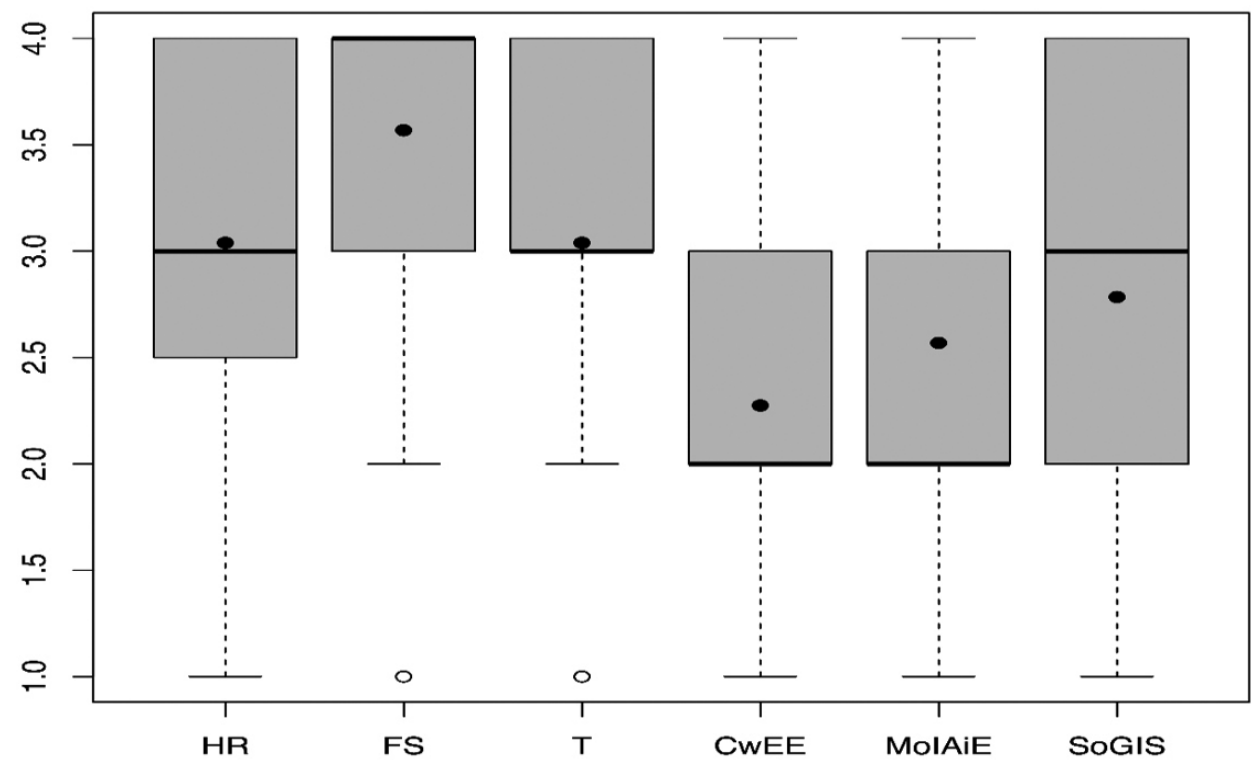

HR - Human resources, FS - Financial sources, T - Technology

CWEE - Cooperation with external entities

MolAiE - Management of innovation activities in enterprises

SoGIS - System of state support for innovation

Graph 1: Box plots of factors affecting innovation activities in Slovak SMEs 
the median and mean are the highest for financial sources, which suggests that financial sources are the factor with the highest impact on innovation activities in Slovak SMEs.

To answer the first research question (Q1) it can be stated, that there is no statistically significant difference in individual (analysed) factors between innovation leaders and non-innovators and between innovation leaders and followers. It means that managers of enterprises have the same view of the importance of the factors regardless of the introduced innovations.

We evaluated also the significance of individual factors determining innovation activities in all three categories of enterprises (Table 4).

Our research confirmed that in all three categories of enterprises (innovation leaders, non-innovators and modest innovators), financial resources are viewed as the most significant factor in innovation activities.

\section{Barriers to innovations in Slovak SMEs}

We defined a checklist of 11 barriers (Table 5) and asked the managers to evaluate the significance of these barriers. The list of 11 barriers was elaborated on the basis of the results from our previous research (Lesáková, et al., 2016; Nemec, 2014). We assumed that Slovak SMEs do not evaluate the barriers to innovations as equally significant, and to verify this premise, we used the Friedman test. The test rejected null hypothesis that that none of the barriers is seen by Slovak SMEs as more or less important than the others ( $p$-value $<2.2 \mathrm{e}-16$ ) and supports our assumption. Table 5 below presents a comparison of the average of individual barriers, standard deviation and median.

Among the most significant barriers were bureaucracy (3.34) - 29 enterprises (57\%) evaluated this barrier as the most serious - then, corruption and state support of innovation activities, which achieved the same average (3.14). 25 enterprises (49\%) considered these two barriers very significant. Inappropriate system of state support for innovation activities was marked as a serious barrier by 23 enterprises (45\%). On the other hand, lack of cooperation with external entities was marked as the least significant barrier $($ mean $=1.96)$.

In the next step, we analysed the differences in evaluation of the main barriers to innovation in the three categories of enterprises - innovation leaders, innovation followers and non-innovative enterprises (Table 6).

There is no statistically significant difference in indicating the main barriers between the three categories of enterprises. The results gained from Fisher exact test $(p$-value $=0.11)$ indicated only a small difference in corruption. They confirmed a statistically significant difference between the leading enterprises and modest innovators (innovation followers) in evaluating the corruption barrier $(p$-value $=0.076)$.

Table 4: Evaluating factors determining innovation activities in three categories of SMEs by importance on scale 1 - 4 (4 means the highest importance and 1 the lowest importance)

\begin{tabular}{|c|c|c|c|c|c|c|c|c|}
\hline \multirow{2}{*}{ Factors } & \multicolumn{2}{|c|}{ All enterprises } & \multicolumn{2}{|c|}{ Leaders } & \multicolumn{2}{|c|}{ Modest innovators } & \multicolumn{2}{|c|}{ Non-innovative SMEs } \\
\hline & $\begin{array}{c}\text { Mean } \\
\text { (SD) }\end{array}$ & $\begin{array}{c}\text { Median } \\
\text { (IQR) }\end{array}$ & $\begin{array}{c}\text { Mean } \\
\text { (SD) }\end{array}$ & $\begin{array}{c}\text { Median } \\
\text { (IQR) }\end{array}$ & Mean (SD) & $\begin{array}{c}\text { Median } \\
\text { (IQR) }\end{array}$ & $\begin{array}{l}\text { Mean } \\
\text { (SD) }\end{array}$ & $\begin{array}{c}\text { Median } \\
\text { (IQR) }\end{array}$ \\
\hline Human resources & $\begin{array}{c}3.04 \\
(0.98)\end{array}$ & $\begin{array}{c}3.0 \\
(1.5)\end{array}$ & $\begin{array}{c}3.46 \\
(0.66)\end{array}$ & $\begin{array}{c}4.0 \\
(1.0)\end{array}$ & $2.79(1.02)$ & $\begin{array}{c}3.0 \\
(2.0)\end{array}$ & $\begin{array}{c}3.07 \\
(1.07)\end{array}$ & $\begin{array}{c}3.0 \\
(1.0)\end{array}$ \\
\hline Financial sources & $\begin{array}{c}3.57 \\
(0.67)\end{array}$ & $\begin{array}{c}4.0 \\
(1.0)\end{array}$ & $\begin{array}{c}3.54 \\
(0.66)\end{array}$ & $\begin{array}{c}4.0 \\
(1.0)\end{array}$ & $3.50(0.78)$ & $\begin{array}{c}4.0 \\
(1.0)\end{array}$ & $\begin{array}{c}3.71 \\
(0.47)\end{array}$ & $\begin{array}{c}4.0 \\
(0.8)\end{array}$ \\
\hline Technology & $\begin{array}{c}3.04 \\
(0.82)\end{array}$ & $\begin{array}{c}3.0 \\
(1.0)\end{array}$ & $\begin{array}{c}3.23 \\
(0.73)\end{array}$ & $\begin{array}{c}3.0 \\
(1.0)\end{array}$ & $2.75(0.79)$ & $\begin{array}{c}3.0 \\
(1.0)\end{array}$ & $\begin{array}{c}3.36 \\
(0.84)\end{array}$ & $\begin{array}{c}3.5 \\
(1.0)\end{array}$ \\
\hline $\begin{array}{l}\text { Cooperation with } \\
\text { external entities }\end{array}$ & $\begin{array}{c}2.27 \\
(0.96)\end{array}$ & $\begin{array}{c}2.0 \\
(1.0)\end{array}$ & $\begin{array}{c}2.62 \\
(1.04)\end{array}$ & $\begin{array}{c}3.0 \\
(1.0)\end{array}$ & $2.17(0.96)$ & $\begin{array}{c}2.0 \\
(0.0)\end{array}$ & $\begin{array}{c}2.14 \\
(0.86)\end{array}$ & $\begin{array}{c}2.0 \\
(0.8)\end{array}$ \\
\hline $\begin{array}{l}\text { Management of in- } \\
\text { novation activities } \\
\text { in enterprises }\end{array}$ & $\begin{array}{c}2.57 \\
(0.90)\end{array}$ & $\begin{array}{c}2.0 \\
(1.0)\end{array}$ & $\begin{array}{c}2.69 \\
(0.95)\end{array}$ & $\begin{array}{c}3.0 \\
(1.0)\end{array}$ & $2.50(0.93)$ & $\begin{array}{c}2.0 \\
(1.0)\end{array}$ & $\begin{array}{c}2.57 \\
(0.85)\end{array}$ & $\begin{array}{c}2.5 \\
(1.0)\end{array}$ \\
\hline $\begin{array}{l}\text { System of state } \\
\text { support for inno- } \\
\text { vation }\end{array}$ & $\begin{array}{c}2.78 \\
(1.06)\end{array}$ & $\begin{array}{l}3.0 \\
(2.0)\end{array}$ & $\begin{array}{c}3.23 \\
(1.01)\end{array}$ & $\begin{array}{c}4.0 \\
(1.0)\end{array}$ & $2.42(1.02)$ & $\begin{array}{c}2.0 \\
(1.0)\end{array}$ & $\begin{array}{c}3.00 \\
(1.04)\end{array}$ & $\begin{array}{c}3.0 \\
(1.0)\end{array}$ \\
\hline
\end{tabular}


Table 5: Barriers to innovations in Slovak SMEs by importance on scale 1 - 4 (4 means the highest importance and 1 the lowest importance)

\begin{tabular}{|c|c|c|}
\hline \multirow{2}{*}{ Barriers } & \multicolumn{2}{|c|}{ All enterprises } \\
\cline { 2 - 3 } & Mean (SD) & Median (IQR) \\
\hline Bureaucracy & $3.34(0.92)$ & $4.00(1.00)$ \\
\hline Corruption & $3.14(1.03)$ & $3.50(1.75)$ \\
\hline Inappropriate system of state support for innovation & $3.14(0.99)$ & $3.00(1.00)$ \\
\hline High costs for innovations & $2.98(0.72)$ & $3.00(0.00)$ \\
\hline Lack of internal financial sources & $2.82(0.97)$ & $3.00(1.00)$ \\
\hline Difficulty in obtaining of external financial sources & $2.80(1.04)$ & $3.00(2.00)$ \\
\hline Insufficiently qualified labour force & $2.35(1.05)$ & $2.00(2.00)$ \\
\hline Lack of knowledge about benefits of R\&D in enterprise & $2.00(0.96)$ & $2.00(2.00)$ \\
\hline Lack of willingness to innovate & $1.98(0.98)$ & $2.00(2.00)$ \\
\hline Absence of innovation strategy & $1.98(0.97)$ & $2.00(1.00)$ \\
\hline Lack of cooperation with external entities & $1.96(0.98)$ & $2.00(1.00)$ \\
\hline
\end{tabular}

Table 6: Barriers to innovations in Slovak SMEs according to three categories of enterprises

\begin{tabular}{|c|c|c|c|c|c|c|}
\hline \multirow[b]{2}{*}{ Barriers } & \multicolumn{2}{|c|}{ Leaders } & \multicolumn{2}{|c|}{ Modest innovators } & \multicolumn{2}{|c|}{ Non-innovative SMEs } \\
\hline & Mean (SD) & $\begin{array}{l}\text { Median } \\
\text { (IQR) }\end{array}$ & $\begin{array}{l}\text { Mean } \\
(\text { SD) }\end{array}$ & $\begin{array}{l}\text { Median } \\
(\text { IQR) }\end{array}$ & $\begin{array}{l}\text { Mean } \\
(\text { SD) }\end{array}$ & $\begin{array}{l}\text { Median } \\
\text { (IQR) }\end{array}$ \\
\hline Bureaucracy & $3.75(0.62)$ & $\begin{array}{l}4.00 \\
(0.00)\end{array}$ & $\begin{array}{l}3.13 \\
(0.99)\end{array}$ & $\begin{array}{l}3.00 \\
(1.25)\end{array}$ & $\begin{array}{c}3.36 \\
(0.93)\end{array}$ & $\begin{array}{c}4.00 \\
(1.00)\end{array}$ \\
\hline Corruption & $3.75(0.62)$ & $\begin{array}{l}4.00 \\
(0.00)\end{array}$ & $\begin{array}{c}2.88 \\
(1.08)\end{array}$ & $\begin{array}{l}3.00 \\
(2.00)\end{array}$ & $\begin{array}{c}3.07 \\
(1.07)\end{array}$ & $\begin{array}{c}3.00 \\
(1.00)\end{array}$ \\
\hline $\begin{array}{l}\text { Inappropriate system of state support } \\
\text { for innovation }\end{array}$ & $3.58(0.67)$ & $\begin{array}{c}4.00 \\
(1.00)\end{array}$ & $\begin{array}{c}2.79 \\
(1.06)\end{array}$ & $\begin{array}{l}3.00 \\
(2.00)\end{array}$ & $\begin{array}{c}3.36 \\
(0.93)\end{array}$ & $\begin{array}{c}4.00 \\
(1.00)\end{array}$ \\
\hline High cost for innovations & $2.92(0.79)$ & $\begin{array}{l}3.00 \\
(1.25)\end{array}$ & $\begin{array}{l}2.96 \\
(0.75)\end{array}$ & $\begin{array}{c}3.00 \\
(0.00)\end{array}$ & $\begin{array}{l}3.08 \\
(0.64)\end{array}$ & $\begin{array}{c}3.00 \\
(0.00)\end{array}$ \\
\hline Lack of internal financial sources & $2.75(1.14)$ & $\begin{array}{l}3.00 \\
(0.75)\end{array}$ & $\begin{array}{c}2.79 \\
(0.93)\end{array}$ & $\begin{array}{c}3.00 \\
(1.00)\end{array}$ & $\begin{array}{c}2.92 \\
(0.95)\end{array}$ & $\begin{array}{l}3.00 \\
(2.00)\end{array}$ \\
\hline $\begin{array}{l}\text { Difficulty in obtaining of external } \\
\text { financial sources }\end{array}$ & $2.83(1.11)$ & $\begin{array}{l}3.00 \\
(2.00)\end{array}$ & $\begin{array}{c}2.70 \\
(1.11)\end{array}$ & $\begin{array}{c}2.00 \\
(2.00)\end{array}$ & $\begin{array}{c}2.93 \\
(0.92)\end{array}$ & $\begin{array}{c}3.00 \\
(1.50)\end{array}$ \\
\hline Insufficiently qualified labour force & $2.58(1.16)$ & $\begin{array}{c}3.00 \\
(1.50)\end{array}$ & $\begin{array}{l}2.25 \\
(0.94)\end{array}$ & $\begin{array}{c}2.00 \\
(1.25)\end{array}$ & $\begin{array}{c}2.31 \\
(1.18)\end{array}$ & $\begin{array}{l}2.00 \\
(2.00)\end{array}$ \\
\hline $\begin{array}{l}\text { Lack of knowledge about benefits of } \\
\text { R\&D in enterprise }\end{array}$ & $1.62(0.96)$ & $\begin{array}{c}1.00 \\
(1.00)\end{array}$ & $\begin{array}{c}2.21 \\
(0.98)\end{array}$ & $\begin{array}{c}2.00 \\
(2.00)\end{array}$ & $\begin{array}{c}2.00 \\
(0.85)\end{array}$ & $\begin{array}{l}2.00 \\
(2.00)\end{array}$ \\
\hline Lack of willingness to innovate & $2.15(0.99)$ & $\begin{array}{l}2.00 \\
(2.00)\end{array}$ & $\begin{array}{c}1.92 \\
(1.02)\end{array}$ & $\begin{array}{l}2.00 \\
(2.00)\end{array}$ & $\begin{array}{l}1.92 \\
(0.95)\end{array}$ & $2.00(1.00)$ \\
\hline Absence of innovation strategy & $2.15(1.07)$ & $\begin{array}{l}2.00 \\
(2.00)\end{array}$ & $\begin{array}{c}1.92 \\
(0.88)\end{array}$ & $\begin{array}{c}2.00 \\
(1.25)\end{array}$ & $\begin{array}{c}1.92 \\
(1.08)\end{array}$ & $2.00(1.00)$ \\
\hline $\begin{array}{c}\text { Lack of cooperation with external } \\
\text { entities }\end{array}$ & $2.25(1.22)$ & $\begin{array}{l}2.00 \\
(2.25)\end{array}$ & $\begin{array}{l}1.96 \\
(0.91)\end{array}$ & $\begin{array}{l}2.00 \\
(1.00)\end{array}$ & $\begin{array}{l}1.69 \\
(0.85)\end{array}$ & $1.00(1.00)$ \\
\hline
\end{tabular}


Results of statistical analysis enable to answer the second research question $(\mathrm{Q} 2)$. Innovation leaders indicated bureaucracy $($ mean $=3.75)$ and corruption $($ mean $=3.75)$ as the most significant barrier and state support of innovation activities as a significant barrier $($ mean $=3.58)$. Bureaucracy and corruption were marked as significant barriers also by modest innovators $($ mean $=3.13)$. High cost of innovations was a significant barrier for innovation followers. Inappropriate state support of innovation activities is another significant barrier, especially for non-innovative SMEs $($ mean $=3.36)$.

It can be concluded that a majority of enterprises see the main barriers to developing innovation activities in: 1 . bureaucracy and corruption, 2 . inappropriate state support of innovation activities, 3. high cost of innovation and 4. lack of financial resources.

Based on the test results, and the fact that our sample size was sufficiently large to identify large and medium differences between the sample and the population with respect to chosen criteria, as well as large and medium effect sizes, we concluded that our sample of enterprises can be seen as a reasonable sample of the entire population of small and medium enterprises.

\section{Discussion and conclusion}

Research results confirmed that managers of all three categories of enterprises have the same or a very similar opinion on the significance of the factors and barriers, regardless of the type and number of innovations. No statistically significant difference was confirmed here.

In the following part, we will briefly conclude the results of the research aimed at identification of key factors and barriers of innovation activities in Slovak SMEs. The main implications are basic recommendations for state policy makers as well as SMEs' managers to foster innovation activities in enterprises. We can summarise them as follows:

1. Innovation leaders, modest innovators and non-innovative firms see financial resources as the most significant factor for innovation activities (see Table 4). For the future, it will be necessary to mobilise all financial sources in the area of innovation support in order to ensure that innovation activities performed by business entities receive the same level of funding as those in advanced EU countries. In connection with the efforts towards the most effective use of allocated financial resources, the state will have to provide indirect aid to profit-generating projects implemented by SMEs, i.e. it will have to use financial engineering instruments such as guarantee funds, credit funds, venture capital funds and municipal development funds. There is an enormous interest of competent institutions in coordination with the Ministry of Finance of the Slovak Republic to apply an upgraded model of usage of innovative financial tools in order to support innovation activities in SMEs (Country Report Slovakia, 2016). Slovakia has set a target to increase expenditures on research and development to $1.2 \%$ of GDP by 2020 . To support the financing of innovations, the situation should be changed not only by one way financial support from state budget, but also by increasing the resources of businesses, which in 2020, should account for $2 / 3$ of the total resources spent on $R \& D$. This implies much greater involvement of SMEs in research. The state should adopt measures that would encourage businesses to be much more engaged in research, development and innovation. We see a solution also in overall improvement of the business environment, for example, through a reduction of indirect taxes - especially VAT rate, reduction of contributions to social and health insurance companies, and in all the other areas mentioned above.

2. High-quality human resources were indicated as an important prerequisite for developing innovation activity (see Table 3 ). The results showed a small difference between innovation leaders and non-innovators (see Table 4). Quality management and employees able to think creatively and implement innovations in their activity are crucial to the development of innovation activity of an enterprise. The management must be able to lead and direct the thoughts and ideas in the enterprise, search and use talents, and must be also aware of the fact that the enterprise will be successful due to being distinguished by the human resources (Frappaolo, 2006). The demand for creative workers should motivate Slovak secondary schools and universities to equip their students with such competencies that would accommodate their future employers. Each business subject should be more actively involved in the educational process (Janson, Cecez-Kecmanovic, \& Zupančič, 2007). A solution to this problem could be "dual educational system", which has been recently launched in Slovak secondary vocational schools. Firms could also give more support to lifelong learning of their employees to improve their qualifications and skills needed for the implementation of innovative actions. These educational activities should be carried out in cooperation with cluster organizations, industrial chambers and associations operating in Slovakia, as well as regional authorities and municipalities. Employees are expected to have a pro-active approach and to be willing to learn and implement new knowledge in the innovation activity. On the other hand, they must be adequately rewarded for their innovation ideas, for their increased effort to search for new, innovative solutions (Lesáková, 2009). 
3. Another factor significant for the development of innovation activity is cooperation and participation of SMEs in different networks and clusters (on scale 1-4 where 4 means the highest importance and 1 means the lowest importance means was 2.27). It is surprising that for $49.0 \%$ of the responded enterprises, cooperation with external entities in innovations has a lower importance (see Table 3). Modest innovators reported a significantly lower level of cooperation $($ mean $=2.17)$. The positive examples from EU countries confirm that participation of small and medium enterprises in networks and clusters and support of partnerships is a way to involve small and medium enterprises in innovation activities (Cygler, Gajdzik, \& Sroka, 2014). Innovation process of a higher level calls for improvement of interaction between small and medium enterprises, research institutions and universities and for creation of effective networks and partnerships (Lesáková, 2009). Creating a partnership is a way to get involved in innovation activities. Cooperation of SMEs with other organisations in the field of innovation activities brings several synergic effects to the enterprise. The most important of them is sharing of knowledge and a similar approach to the latest know-how, sharing of capacities, a lower demand for financial sources, etc. Support to innovative industrial cluster organisations is also one of the main measures in the Innovation Strategy of the Slovak Republic for the years $2014-2020$. The purpose is to improve the competitiveness of these organisations through support of their selected activities with a view to promote joint industrial activities in selected areas (Innovation Strategy of the SR for $2014-2020$ ).

4. According to the research results, the government should pay much more attention to systematic institutional support to SMEs on the national and regional level (see Table 4). All enterprises (innovation leaders, modest innovators and non-innovators) pointed to the low quality of innovation support. Inappropriate state support of innovation activities is a significant barrier (see Table 5), especially for non-innovative enterprises (see Table 6 , mean $=3.36$ ). Of special importance is the development of institutions supporting innovation activities on the national and regional level. Setting up regional innovation centres would foster implementation of the regional and state innovation policy in regions and thus increase the competitiveness and employment at the regional level and reduce regional disparities. Regional innovation centres could help to start cooperation between SMEs on the one hand, and universities and research centres on the other hand. A critical point is autonomous functioning of sectors of education, research and innovation (R\&I) and business, which means a different understanding of R\&I. It is necessary to create links between R\&I in multinational companies and in local businesses, including SMEs, and to increase the interest of businesses and industrial clusters to change the structure of industrial R\&I entities. Successful implementation of the innovation strategy requires a structural change of the competencies of the management of research and innovation in Slovakia and a fundamental change in the culture of innovative environment.

5.SMEs' managers agreed on the fact that without a well-created vision and clearly formulated aims, innovation activity in SMEs is limited. The results showed that the management of innovation is a part of the business strategy in the category of innovation leaders $(46 \%-94 \%)$, but it is not the case of many modest innovators and non-innovators. Clearly formulated objectives are a vision depending on the possibilities of the enterprise and the situation in the market. Clear vision is a strong predictor of success (Wagner, \& Hollenbeck, 2012).

6 . And the last precondition that appeared in the answers of managers is willingness of enterprises to innovate. This is an inevitable factor, even if it is connected with a certain risk. The positive thing is that "lack of willingness to innovate" had the lowest rank in all three categories of enterprises (see Table 6). Many innovative SMEs now are successful and perspective and, on the contrary, many enterprises without innovative activity are getting into financial problems. Willingness to innovate should be accompanied by such an environment that will support the rise of innovation activities (Lesáková, 2013). In this way, innovations could be introduced faster and at the same time, the number of barriers retarding the rise of innovation activities could be lower.

The low number of innovative enterprises in Slovakia is a result of innovation barriers that are an obstacle hampering successful development of innovation activities in businesses. Specifically, Slovak enterprises suffer from a lack of financial sources to innovation, which significantly reduces their innovation activity; yet, the major obstacle lies in bureaucracy and corruption.

The explanation why bureaucracy and corruption are viewed by Slovak SMEs as the main barriers (see Table 5) comes from their experience during the process of raising money and developing innovation activities. The enterprises mentioned their negative experience with obtaining finance from the European Union funds or other public financial sources (bureaucratic administration, corruption, ineffective redistribution of finances, as well as ignorance of their drawing).

High cost of innovation was also appeared on the list of significant barriers to innovation for Slovak SMEs. Never- 
theless, managers should take into consideration that innovation is a prerequisite to get a competitive advantage in future.

The respondents expressed a critical opinion about the institutional form of support from the state (see Table 5) - about the existence and activities of institutions supporting innovation activities as well as the support of the rise and development of innovative SMEs. Critically are also viewed Slovak regional offices in terms of the missing regional innovation structures; there is no scheme for effective management of the state innovation policy and regional innovation strategies. The respondents were critical to the long-term absence of regional innovation centres, which should help to start cooperation between SMEs on the one hand, and universities, research centres, technological parks on the other hand, and to enhance the process of establishing clusters.

Some of the barriers can be eliminated at the level of enterprise, but most of them require solutions at the state level. Therefore, the task for the state is to ensure adequate inputs (sources) for innovation activities and create suitable conditions, i.e. an environment that can stimulate development of innovation.

Our research is a scan of the current situation of identification key factors and barriers determining innovation activities in Slovak SMEs and offers a lot of space to improve. The biggest limitations of this study is a small response rate of the questionnaire which prevented us from taking our statistical analyses further. Consequently, the presented results should be interpreted primarily from the exploratory point of view. Limitations of our study create opportunities for future research. In the future we plan to focus on higher number of enterprises, including enterprises of various size (small, medium-sized and large enterprises) and also from various countries. It would be very interesting to repeat our primary research in other countries than Slovakia for the purpose of making international comparison of identification (evaluation) of key factors and barriers determining innovation activities in SMEs.

\section{Acknowledgement}

The research was supported by the National Scientific Agency of the Ministry of Education of the Slovak Republic (research project VEGA 1/0494/15 "The research of factors influencing the successfulness of innovative small and medium enterprises in the Slovak Republic").

\section{Literature}

Adair, J. (2009). Leadership for Innovation. London: Kogan Page Limited.

Bessant, J., \& Tidd, J. (2009). Innovation and entrepreneurship. Chichester: John Wiley \& Sons Ltd, West
Sussex, England.

Cooke, Ph., \& Wills, D. (1999). Small firms, social capital and the enhancement of business performance through innovation programmes. Small Business Economics. 13(3), 219-234, https://doi. org/10.1023/A:1008178808631

Country Report Slovakia. (2016). European Commission, Brussels. Retrieved February 26, 2016, from http:// ec.europa.eu/europe2020/pdf/csr2016/cr2016_slovakia_en.pdf

Cygler, J., Gajdzik, B., \& Sroka, W. (2014). Coopetition as a development stimulator of enterprises in the networked steel sector. Metalurgija. 53(3), 383-386.

Cheah, P., Lang, A., Snowden, S., \& Watts, S. (2014). PwC $17^{\text {th }}$ annual global CEI survey. Retrieved October 30, 2017, from https://www.pwc.com/gx/en/ ceo-survey/2014/assets/pwc-17th-annual-global-ceosurvey-jan-2014.pdf/

Di Cintio, M., Ghosh, S., \& Grassia, E. (2017). Firm growth, R\&D expenditures and exports: An empirical analysis of Italian SMEs. Research Policy. 46. 836852, http://dx.doi.org/10.1016/j.respol.2017.02.006

Drucker, P. (1985). Innovation and entrepreneurship. London: Heinemann.

European Commission. (2010). Europe 2020. A strategy for smart, sustainable and inclusive growth. European Commission: Brussels, Belgium.

Frappaolo, C. (2006). Knowledge Management. Chichester: Capstone Publishing Ltd.

Hoffman, K., et al. (1998). Small firms, R\&D technology and innovation in the U.K.: a literature review. Technovation. 18(1), 39-55, https://doi.org/10.1016/S01664972(97)00102-8

Janson, M., Cecez-Kecmanovic, D., \& Zupančič, J. (2007). Prospering in a transition economy through information technology-supported organizational learning. Information System Journal. 17(1), 3-36, http://dx.doi. org/10.1111/j.1365-2575.2006.00228.x

Jones, B., \& Miller, B. (2007). Innovation Diffusion in the New Economy. Abingdon: Routledge.

Keizer, J., et al. (2002). Explaining innovative efforts of SMEs. An exploratory survey among SMEs in the mechanical and electrical engineering sector in the Netherlands. Technovation. 22(1), 1-13, https://doi. org/10.1016/S0166-4972(00)00091-2

Kressel, H., \& Lento, T. (2012). Entrepreneurship in the global economy. Engine for economic growth. Cambridge: Cambridge University Press.

Labovitz, S. (1968). Criteria for Selecting a Significance Level: A Note on the Sacredness of .05. The American Sociologist, 3(3), 220-222.

Lee, R., Lee, J., \& Garett, T. C. (2017). Synergy effects of innovation on firm performance. Journal of Business Research, http://dx.doi.org/10.1016/j.jbusres.2017.08.032 
Lesáková, L., et al. (2016). Klúčové faktory inovačnej činnosti malých a stredných podnikov v Slovenskej republike. Banská Bystrica: Belianum.

Lesáková, L. (2014). Evaluating innovations in small and medium enterprises in Slovakia. Procedia - social and behavioural sciences: contemporary issues in business, management and education. 110, 74-81, https:// doi.org/10.1016/j.sbspro.2013.12.849

Lesáková, L. (2013). Behavioural norms as an element supporting creativity and innovation in small and medium enterprises. In Contemporary challenges towards management III. (pp. 99-107). Katowice: Wydawnictwo Uniwersytetu Slaskiego.

Lesáková, L. (2009). Innovations in Small and Medium Enterprises in Slovakia. Acta Polytechnica Hungarica: Journal of Applied Sciences. 6(3), 23-34.

Maletič, M., et al. (2014). The Relationship between Sustainability-Oriented Innovation Practices and Organizational Performance: Empirical Evidence form Slovenian Organizations. Organizacija. 47(1), 3-12, https:// doi.org/10.2478/orga-2014-0001

Ministry of Economy of the Slovak Republic. (2014). Innovation Strategy of the Slovak Republic for the years 2014 - 2020. Retrieved March 4, 2017 from http:// www.lt.justice.gov.sk/

Nemec, E. (2014). Predpoklady vzniku a rozvoja inovativnych malých a stredných podnikov v Slovenskej republike. Dissertation thesis. Banská Bystrica: Faculty of Economics, Matej Bel University.

Nooteboom, B., \& Stam, E. (2008). Micro-foundatiuons for Innovation Policy. Amsterdam: Amsterdam University Press.

Organisation for Economic Co-operation and Development. (2005). OSLO Manual. Retrieved July 8, 2017 from http://www.oecd.org/dataoecd/35/61/2367580

O'Sullivan, D., \& Dooley, L. (2009). Applying Innovation. London: Sage Publications, United Kingdom.

Peljko, Ž. et al. (2016). An Empirical Study of the Relationship between Entrepreneurial Curiosity and Innovativeness. Organizacija. 49(3). 172-181, https://doi. org/10.1515/orga-2016-0016

Porter, M. (1990). Competitive Advantage of Nations. New York: Free Press.

Szczepańska-Woszczyna, K. (2014). Determinants of innovation activities in small and medium-sized enter- prises in Poland. Journal of Advanced Research in Management. 5(2), 65-73.

Radas, S., \& Božič, L. (2009). The antecedents of SME innovativeness in an emerging transition economy. Technovation. 29(1), 438-450, https://doi.org/10.1016/j. technovation.2008.12.002

Trushman, M. L., \& Nadler, A. D. (1996). Organizing for Innovation. California Management Review. 28 (3), 74-92, https://doi.org/10.2307/41165203

Wagner, J., \& Hollenbeck, J. (2012). Organization behaviour. Securing Competitive Advantage. London: Routledge, Taylor \& Francis Group, Ltd.

L'ubica Lesáková is Professor at the Department of Corporate Economics and Management of the Faculty of Economics of Matej Bel University in Banská Bystrica (Slovak Republic). Her research focuses on small and medium enterprises and innovations. She has published more than 100 articles in scientific journals and proceedings of international conferences.

Petra Gundová is a lecturer at the Department of Corporate Economics and Management of the Faculty of Economics of Matej Bel University in Banská Bystrica (Slovak Republic). In her scientific research, she focuses on issues of the financial analysis of companies and innovations. She has published over 20 articles in scientific journals and proceedings of international conferences.

Pavol Král' received his Ph.D. in Mathematical Analysis from the Matej Bel University in Banská Bystrica. He is an Assistant Professor at the Faculty of Economics, Matej Bel University in Banská Bystrica. His research interests include fuzzy set theory and economic applications of mathematics and statistics. He is a (co)author of more than 30 publications in scientific journals and proceedings of international conferences.

Andrea Ondrušová is a PhD student of the study programme Corporate Economics and Management at the Faculty of Economics of Matej Bel University in Banská Bystrica (Slovak Republic). 


\section{Appendix}

Listed below are only the questions relevant to theme of the article.

Q1: Which type of innovations did you introduce in each year of the analysed period?

\begin{tabular}{|c|c|c|c|c|c|c|}
\hline & $\mathbf{2 0 1 5}$ & $\mathbf{2 0 1 4}$ & $\mathbf{2 0 1 3}$ & $\mathbf{2 0 1 2}$ & $\mathbf{2 0 1 1}$ & $\mathbf{2 0 1 0}$ \\
\hline Product innovations & & & & & & \\
\hline Process innovations & & & & & & \\
\hline Organizational innovations & & & & & & \\
\hline Marketing innovations & & & & & & \\
\hline
\end{tabular}

Q2: Evaluate the importance of the key factors determining innovation activities.

\begin{tabular}{|c|c|c|c|c|}
\hline \multirow{2}{*}{ Factors } & \multicolumn{3}{|c|}{ The importance of factors } \\
\cline { 4 - 5 } & $\begin{array}{c}\text { The lowest } \\
\text { (1) }\end{array}$ & $\begin{array}{c}\text { Lower } \\
\text { (2) }\end{array}$ & $\begin{array}{c}\text { Higher } \\
\text { (3) }\end{array}$ & $\begin{array}{c}\text { The highest } \\
\text { (4) }\end{array}$ \\
\hline Human resources & & & & \\
\hline Financial sources & & & & \\
\hline Technology & & & & \\
\hline Cooperation with external entities & & & & \\
\hline Management of innovation activities in enterprises & & & & \\
\hline System of state support for innovation & & & & \\
\hline
\end{tabular}

\section{Q 3: Evaluate the importance of barriers to innovations.}

\begin{tabular}{|c|c|c|c|c|}
\hline \multirow{2}{*}{ Barriers } & \multicolumn{3}{|c|}{ The importance of barriers } \\
\cline { 4 - 5 } & The lowest & $\begin{array}{c}\text { Lower } \\
\text { (2) }\end{array}$ & $\begin{array}{c}\text { Higher } \\
\text { (3) }\end{array}$ & $\begin{array}{c}\text { The highest } \\
\text { (4) }\end{array}$ \\
\hline Lack of internal financial sources & & & & \\
\hline Difficulty in obtaining of external financial sources & & & & \\
\hline High costs for innovations & & & & \\
\hline Insufficiently qualified labour force & & & & \\
\hline Lack of willingness to innovate & & & & \\
\hline Absence of innovation strategy & & & & \\
\hline Lack of cooperation with external entities & & & & \\
\hline Inappropriate system of state support for innovation & & & & \\
\hline Bureaucracy & & & & \\
\hline Corruption & & & & \\
\hline Lack of knowledge about benefits of R\&D in enterprise & & & & \\
\hline
\end{tabular}


Q 4: Evaluate motives to realize the innovation activities $(5=$ the most important motive, $1=$ the less important motive).

\begin{tabular}{|l|l|}
\hline & Growing competition at the market \\
\hline & The effort to keep the customer at the market \\
\hline & The innovation impulse coming from employees \\
\hline & The effort to enter on new (foreign) markets \\
\hline & Changes in the legislative requirements \\
\hline & Possibility to cooperate with another company, resp. institutions \\
\hline & The innovation impulse coming from owner of \\
\hline & Possibility to gain the financial as well as non-financial support from the state or from the EU \\
\hline
\end{tabular}

$Q 28:$ What is the number of SK NACE of your enterprises?

Q 29: Indicate the region where your enterprises is located.

- Bratislava region

- Trnava region

- Trenčín region

- Nitra region

- Banská Bystrica region

- Žilina region

- Prešov region

- Košice region

$Q$ 30: Indicate the number of employees in your enterprises.

- 0 - 9 employees (micro enterprises)

- 10 - 49 employees (small enterprises)

- 50 - 249 employees (medium enterprises)

- 250 employees and more (big enterprises) 